\title{
Expression of phospholipase $C \beta 1$ in olive flounder (Paralichthys olivaceus) following external stress stimulation
}

\author{
Soo Ji Woo ${ }^{1 \dagger}$, Hee Young Jang ${ }^{1 \dagger}$, Hyung Ho Lee ${ }^{2}$ and Joon Ki Chung ${ }^{1 *}$
}

\begin{abstract}
In this study, to clarify the function of PoPLC- $\beta 1$, in response to stress challenge, we examined the PoPLC- $\beta 1$ expression pattern in response to external stress (pathogen-associated molecular pathogen challenge and environmental challenge including temperature and salinity). PoPLC- $\beta 1$ expression analysis of tissue from olive flounder showed that the messenger RNA (mRNA) was predominantly expressed in the brain, heart, eye, liver, spleen, and stomach. We also tested the mRNA expression of the PoPLC- $\beta 1$ in the spleen and kidney of olive flounder by RT-PCR and real-time PCR following stimulation with lipopolysaccharide (LPS), concanavalin A (ConA), or polyinosinic:polycytidylic acid (Polyl:C) and compared with the inflammatory cytokines IL-1b and IL-6 in the stimulated flounder tissues. Each of the spleen and kidney and mRNA transcripts of PoPLC- $\beta 1$ were increased 30and 10-fold than normal tissue at 1-6 h post injection (HPI) with Polyl:C when the expression of PoPLC- $\beta 1$ transcript was similar to LPS and ConA. We also tested the expression of PoPLC- $\beta 1$ in response to temperature and salinity stress. The expression of PoPLC- $\beta 1$ also was affected by temperature and salinity stress. Our results provide clear evidence that the olive flounder PLC- $\beta 1$ signal pathways may play a critical role in immune function at the cellular level and in inflammation reactions. In addition, PLC- $\beta 1$ appears to act as an oxidative-stress suppressor to prevent cell damage in fish.
\end{abstract}

Keywords: Phospholipase C beta 1 (PLC- $\beta 1$ ), Olive flounder, Paralichthys olivaceus, Stress response, mRNA expression

\section{Background}

In marine organisms, environmental changes in the water cause a variety of physiological stress responses, such as changes in oxidative stress, decline in immunity, and changes in plasma components. Among these responses, changes in the immune system are particularly important in the context of fish disease outbreaks in the face of environmental change. Physical factors, such as extreme salinity and temperature changes, affect growth, metabolism, osmoregulation reproductive function, and immune function (Ackerman et al. 2000; Borski et al. 1994; Sampaio and Bianchini 2002; Bly and Clem 1992; Bowden 2008; Schreck et al. 1989; Britoa et al. 2000). Furthermore, stress induced by changes in salinity and

\footnotetext{
* Correspondence: jkchung@pknu.ac.kr

${ }^{\dagger}$ Equal contributors

'Department of Aquatic Life Medicine, Pukyong National University, Busan

608-737, South Korea

Full list of author information is available at the end of the article
}

temperature has been associated with enhanced generation of reactive oxygen species (ROS) in fish, which may seriously affect their immune function and antioxidant defense abilities (Paital and Chainy 2010; An et al. 2010; Kim and Kang 2015).

Phosphoinositide-specific phospholipase C (PLC) enzymes have been shown to play a role in immune responses in mammals; however, little is known about their function in marine organisms in response to stress. PLC is a family of enzymes that hydrolyzes the inner membrane element phosphatidylinositol-4,5-bisphosphate $\left(\mathrm{PIP}_{2}\right)$ to produce inositol 1,4,5-trisphosphate $\left(\mathrm{IP}_{3}\right)$ and diacylglycerol (DAG) (Rhee 2001). $\mathrm{IP}_{3}$ binds to $\mathrm{IP}_{3}$-specific receptors on the membrane of the endoplasmic reticulum (ER), inducing the release of $\mathrm{Ca}^{2+}$ level from the intracellular cytoplasm. While DAG initiates the activation of Ras proteins along with this $\mathrm{Ca}^{2+}$ release, which in turn activates protein kinase $\mathrm{C}$ 
(PKC) (Bunney and Katan 2011). Thirteen PLC isozymes have been cloned from mammalian species to date and have been classified into six classes according to their structures and mechanism of actions: PLC- $\beta$ (1-4), PLC- $\gamma$ ( 1 and 2), PLC- $\delta$ (1, 3, and 4), PLC- $\varepsilon$, PLC- $\zeta$, and the recently identified PLC- $\eta$ ( 1 and 2) (Rebecchi and Pentyala $2000)$. The PLC- $\beta$ subfamily (1-4) has a significantly conserved structure of an N-terminal pleckstrin homology $(\mathrm{PH})$ domain, four EF hand repeats, a triose phosphate isomerase (TIM)-like barrel domain split into an X and Y catalytic domain, a $\mathrm{C} 2$ domain, and a C-terminal (CT) domain (Otaegui et al. 2010). The PH domain plays a minor role in association to the membrane (Tall et al. 1997), whereas its most important role is in mediating protein-protein interactions. The EF hand repeats support the loop related to stimulation of GTP hydrolysis. The catalytic $\mathrm{X}$ and $\mathrm{Y}$ domains are necessary for the catalysis of $\mathrm{PIP}_{2}$ to $\mathrm{IP}_{3}$ and DAG (Song et al. 2001). The C2 domain serves as an intra- and intermolecular regulatory binding position, and the CT domain, the most unique feature, interacts with the GTP-bound $\alpha$ subunit of heterotrimeric G proteins to stimulate PLC- $\beta$ (Singer et al. 2002).

The identified signaling molecules of PLCs have also been suggested to perform a role in the regulation of chemokine-mediated cell migration. There is substantial evidence suggesting a role of PLC- $\beta$ in the immune response. PLC- $\beta$ activity is started by G protein coupled receptor (GPCR)-mediated signal pathway (Kim et al. 2011). PLC- $\beta$ plays an essential role in T cell chemotaxis (Bach et al. 2007) and has previously been shown to participate in several aspects of lymphocyte function, including cell proliferation, rescue from apoptosis, and $\mathrm{CD}^{+}$and $\mathrm{CD}^{+} \mathrm{T}$ cell differentiation (Sasaki et al. 2000; Ward and Cantrell 2001).

The stimulatory effects of lipopolysaccharide (LPS), concanavalin A (ConA), and polyinosinic:polycytidylic acid (PolyI:C) induced the activity of PKC and other mitogens. Previous studies have shown that LPS, ConA, and PolyI:C stimulation induced phosphoinositide-specific PLC (PI-PLC) and phosphatidylcholine-specific PLC (PCPLC) expression of the kidney and spleen. (Chen et al. 1998; Wang et al. 1998; Schütze et al. 1992). Thus, the stimulatory effect contributes to both the innate and adaptive immune responses. However, unlike the signaling pathways of mammalian PLC isoforms, the intra and intercellular signaling pathways of marine organisms remain relatively elusive.

In particular, at the moment, only a few studies have examined the function of PLC- $\beta 1$ in response to stress challenge. Here, therefore, we evaluated changes in PLC$\beta 1$ expression in response to external stress, elicited by pathogen-associated molecular pathogen (PAMP) challenge and environmental challenge (temperature and salinity) in the olive flounder (Paralichthys olivaceus).

\section{Methods}

Stimulation with LPS, ConA, and Polyl:C in the kidney and spleen

LPS is a major component of the gram-negative cell wall. ConA triggers a release mechanism similar to that elicited by the specific worm allergen (Keller 1973), and PolyI:C is structurally similar to a double-stranded RNA virus and potent inducer of interferon (IFN) (Akiyama et al. 1985; Manetti et al. 1995). To study the immune response of PLC- $\beta 1$ in the olive flounder (P. olivaceus), we performed immune challenge experiments by using commercially available LPS (Sigma), ConA (Sigma), and PolyI:C (Sigma). Healthy juvenile $P$. olivaceus $(40 \pm 12 \mathrm{~g}$ ) were anesthetized with MS-222 (3-aminobenzoic acid ethyl ester; Sigma, USA) and were intraperitoneally injected with $500 \mu \mathrm{l}$ of LPS $(100 \mu \mathrm{g} / \mathrm{ml})$, ConA $(100 \mu \mathrm{g} / \mathrm{ml})$, PolyI:C $(100 \mu \mathrm{g} / \mathrm{ml})$, and PBS ( $500 \mu \mathrm{l}$; as a control), as per the body mass of the fish. Target tissues were removed from $P$. olivaceus at 0,1 , 3,6 , and $24 \mathrm{~h}$ after injection. All procedures were performed according to the American Veterinary Medical Association guidelines on euthanasia.

\section{Changes in temperature and salinity}

$P$. olivaceus with a mean weight of $32 \pm 7 \mathrm{~g}$ were obtained from a commercial fish farm. The fish were conditioned in aerated $200-1$ tanks at $20{ }^{\circ} \mathrm{C}$ for a week prior to experimentation. During the acclimatization, the fish were fed with a commercial pelleted diet twice a day (at $10: 00$ and 17:00). Half of the water $(30 \% \pm \pm 0.2)$ in the tank was changed every day. Salinity was decreased at $5 \%$ per hour by adding fresh water (Bio Safe $50 \mathrm{ml} /$ $200 \mathrm{l}$ water) and was regulated from $30 \%$ to zero. The water temperature was rapidly increased from 20 to $30{ }^{\circ} \mathrm{C}$ at a rate of $2.5{ }^{\circ} \mathrm{C} / \mathrm{h}$. The brain, gill, heart, liver, spleen, stomach, intestine, kidney, and muscle tissue were analyzed after $24 \mathrm{~h}$. No mortality was observed following injection and environmental stress.

\section{mRNA isolation and CDNA synthesis from $P$. olivaceus}

The total RNA was isolated using the TRIzol kit (Invitrogen), according to the method described by the manufacturer. Complementary DNA (cDNA) was synthesized from this isolated mRNA by using the Transcriptor First Strand cDNA Synthesis Kit (Roche) and then was used as the template for amplification. Purified RNA was quantified on the basis of its optical density at $260 \mathrm{~nm}$ by using a UV spectrophotometer (Ultrospec 6300 pro, Amersham Biosciences). Two micrograms of total RNA was reverse-transcribed with an oligo (dT)18 and random hexamer primers and Superscript $^{\mathrm{tm}}$ III reverse transcriptase (Invitrogen, USA), as per the manufacturer's instruction. Reverse transcription was carried out at $42{ }^{\circ} \mathrm{C}$ for $60 \mathrm{~min}$. 
Expression studies by reverse transcription PCR

In order to analyze the tissue expression of the PoPLC- $\beta 1$ mRNA, reverse transcription (RT)-PCR was performed. The 18SrRNA and $\beta$-actin genes of $P$. olivaceus were used as internal controls. All the PCR cycles were performed as follows: $94{ }^{\circ} \mathrm{C}$ for $5 \mathrm{~min}, 25-30$ cycles (25 cycles for 18SrRNA and $\beta$-actin; 30 cycles for PoPLC- $\beta 1$ ) of $94{ }^{\circ} \mathrm{C}$ for $30 \mathrm{~s}, 58{ }^{\circ} \mathrm{C}$ for $30 \mathrm{~s}, 72{ }^{\circ} \mathrm{C}$ for $20 \mathrm{~s}$, and a final 7 -min elongation step at $72{ }^{\circ} \mathrm{C}$. The amplified PCR products were separated on $1.0 \%$ agarose/TAE gels containing ethidium bromide and visualized with a Gel Doc image analysis system (Bio-Rad, USA). The resultant products were purified via agarose gel extraction (QIAquick ${ }^{\circledR}$ Gel Extraction kit) and sequenced (COSMO Co. Ltd., DNA Sequencing Service, Seoul, Korea).

\section{Quantitative expression analysis of PoPLC- $\beta 1$}

Total RNA from various tissues was prepared as per the previously described method. 18SrRNA from a constitutive expression gene of $\beta$-actin was used as the internal control to verify the real-time PCR reaction. Quantitative real-time PCR for the tissue-specific expression analysis of PoPLC- $\beta 1$ with the gene-specific primers was conducted using a LightCycler 480 II SYBR Green (Roche, Switzerland). The SYBR Green RTPCR assay was performed by the method described previously (Guan et al. 2007) using the $\Delta \Delta C$ t method, and the relative quantitative values were expressed in accordance with the $2-\Delta \Delta \mathrm{Ct}$ method. In addition to investigating stimulation, the experiments also analyzed the expression of interleukins $1 \beta$ and 6 , as they are a lymphocyte mitogen and proinflammatory cytokines (Benveniste 1998).

\section{Results}

Confirmation of the PoPLC- $\beta 1$ sequence

After confirming the sequence of PoPLC- $\beta 1$ with those previously published sequences (Seo et al. 2011), we compared the characteristic regions of PoPLC- $\beta 1$. The deduced product was examined using a specific primer for RT-PCR and quantitative real-time PCR (Table 1).

\section{Tissue-specific distribution of PoPLC- $\beta 1$ mRNAs}

The expression pattern of the PoPLC- $\beta 1$ gene in the brain, eye, gills, heart, esophagus, liver, spleen, pyloric ceca, stomach, intestine, kidney, and muscle was analyzed by RT-PCR and real-time PCR. All tissues showed detectable levels of PoPLC- $\beta 1$ mRNA expression, but expression was especially higher in the brain and heart tissues (Fig. 1).

\section{Changes in PoPLC- $\beta 1$ expression in response to stress Effects of LPS, ConA, and Polyl:C stimulation on PoPLC- $\beta 1$}

In mammals, $G$ protein has been shown to modulate the signal transduction of both PLC- $\beta$ isoforms (Charo et al. 1994; Franci et al. 1995). To evaluate general changes in the expression levels of PLC- $\beta 1$ in P. olivaceus related to the immune response, we used RT-PCR and real-time PCR to compare PoPLC- $\beta 1$ expression to the interleukin gene expression profiles (IL-1 $\beta$, IL-6) in the spleen and kidney, following stimulation of LPS, ConA, and PolyI:C, which play a major role in various disease processes in teleost fish (Figs. 2, 3, and 4).

LPS and ConA stimulation did not induce significant changes in the expression level of PoPLC- $\beta 1$ (Figs. 5 and 6). However, Polyl:C injection in spleen and kidney led to a dramatic increase in the expression of PoPLC- $\beta 1$ at $3 \mathrm{~h}$ post injection, which was increased by more than 10 fold compared to the control groups and a time dependent increase was observed until $24 \mathrm{~h}$ post injection in the spleen and kidney (Fig. 7). As shown in Figs. 4 and 7 , PoPLC- $\beta 1$ expression significantly increased along with the IL-1 $\beta$ and IL- 6 expression in the spleen and kidney following PolyI:C stimulation. The mRNA levels of IL-1 $\beta$ and IL- 6 in the infected spleen and kidney tissues were sharply increased and reached a peak at 3 or $6 \mathrm{~h}$ post injection.

Table 1 Oligonucleotide primers used for the RT-PCR and quantitative real-time PCR to analyze mRNA expression of PLC- $\beta 1$

\begin{tabular}{lll}
\hline Primer name & $5^{\prime}$-3' sequence & Description \\
\hline$\beta$-actin-F & GACATGGAGAAGATCTGGCA & For RT-PCR and real-time qRT-PCR \\
$\beta$-actin-R & ATGTCCTGCTCGAAGTCCAG & GenBank accession no AU090737 \\
$18 \mathrm{~s}$ rRNA-F & GTTGGGGAGCGATTGTCTGG & For RT-PCR and real-time qRT-PCR \\
$18 \mathrm{~s}$ rRNA-R & CATCTAAGGGCATCACAGACCTG & GenBank accession no DQ267937 \\
IL-1 $\beta$-F & AACAGCCAAGGCAAAGATTG & For RT-PCR and real-time qRT-PCR \\
IL-1 $\beta-F$ & AATGTCCAGCTCCTCCTTCA & GenBank accession no AB070835 \\
IL-6-F & TGGGCATCAACTCGGGCTAC & For RT-PCR and real-time qRT-PCR \\
IL-6-R & CGAAGGCCACAGATTGGTC & GenBank accession no DQ267937 \\
PoPLC- $\beta 1-F$ & CAACGTGATGGAGCAAAGAG & For RT-PCR and real-time qRT-PCR \\
PoPLC- $\beta 1-R$ & GGTGTGTGCTCAGTCCGTT & \\
\hline
\end{tabular}




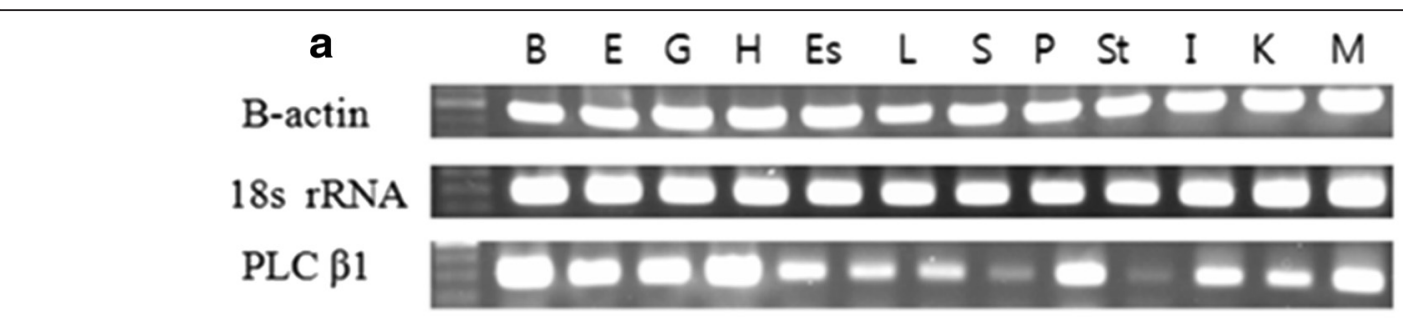

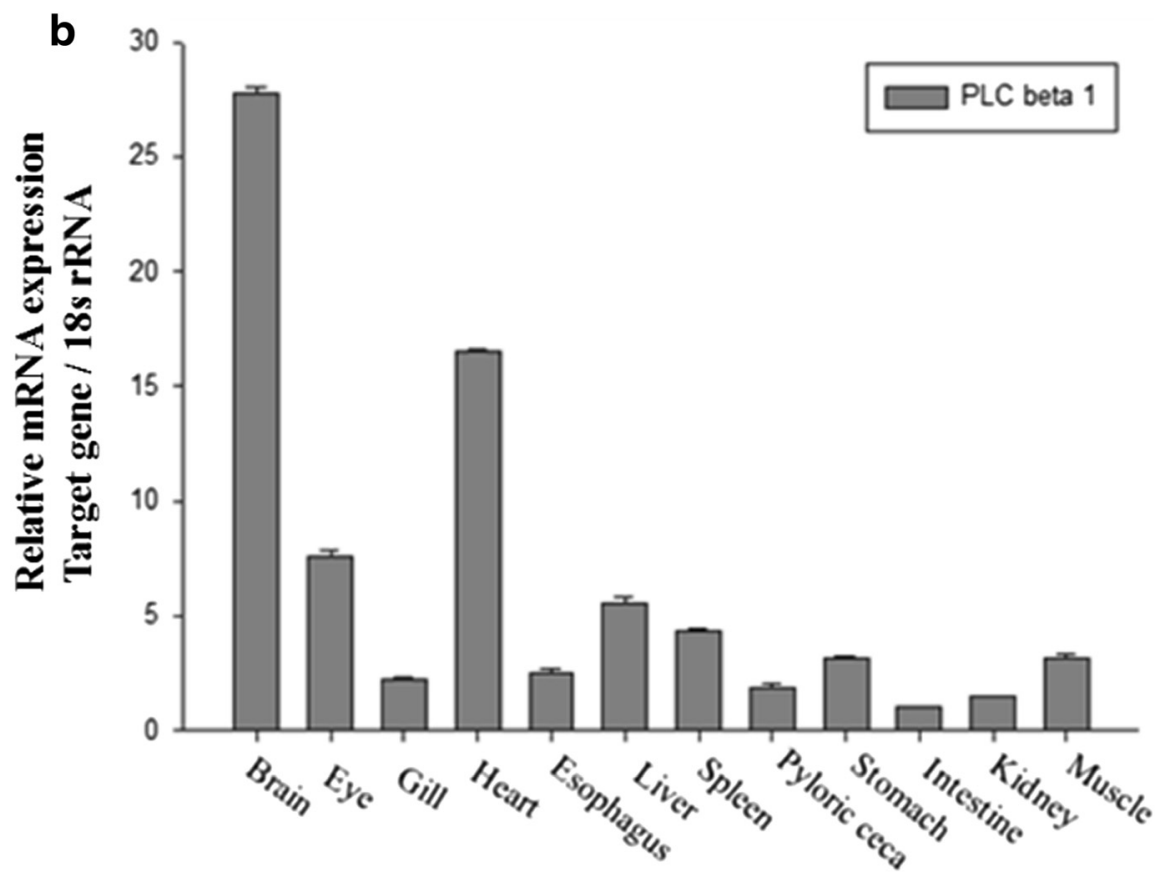

Fig. 1 Tissue-specific distribution of the PoPLC- $\beta 1$ mRNA. a RT-PCR expression analysis of PoPLC- $\beta 1$ in flounder tissues. $\mathbf{b}$ Relative expression of PoPLC- $\beta 1$ in flounder tissues. The olive flounder 18SrRNA gene was used as a reference gene to normalize the expression mRNA levels between sample tissues. Each value is the average of three replicate samples and data are shown as means \pm S.E
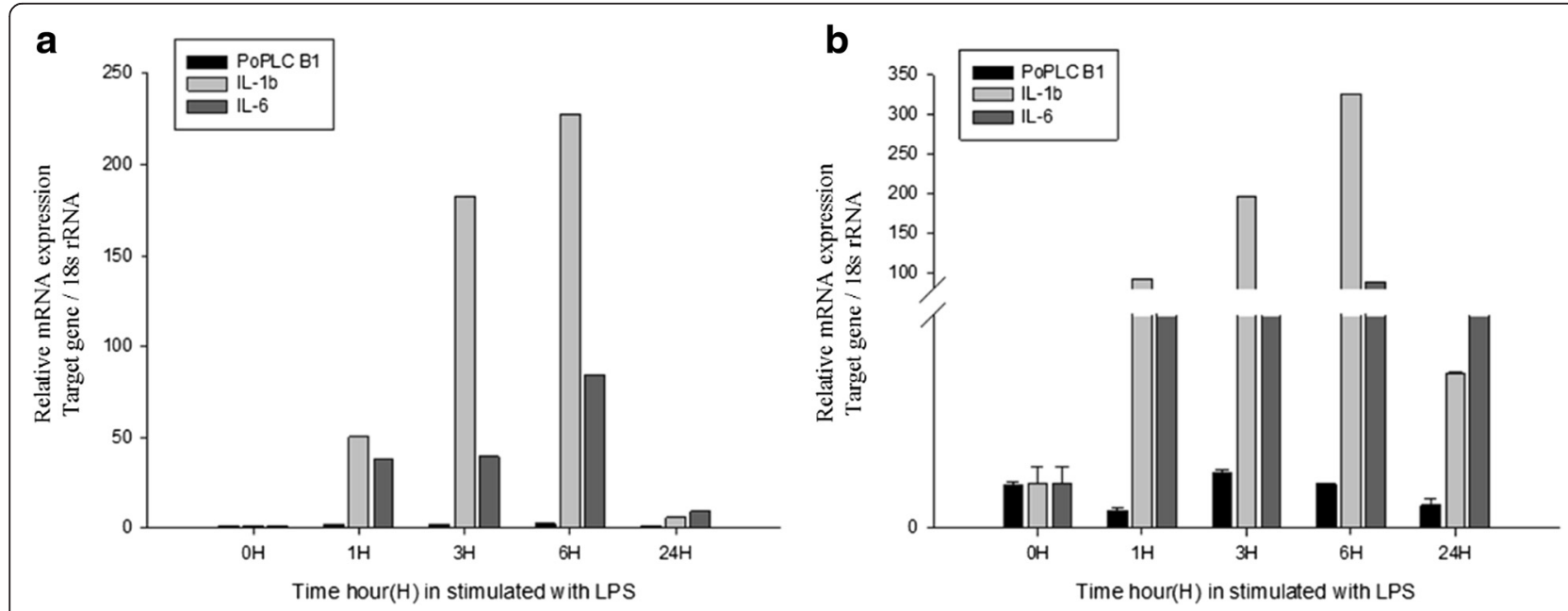

Fig. 2 Real-time PCR analysis of PoPLC- $\beta 1, I L-1 \beta, I L-6$, and 18SrRNA following stimulation with LPS from the a spleen and $\mathbf{b}$ kidney tissue at $0,1,3,6$, and $24 \mathrm{~h}$ 

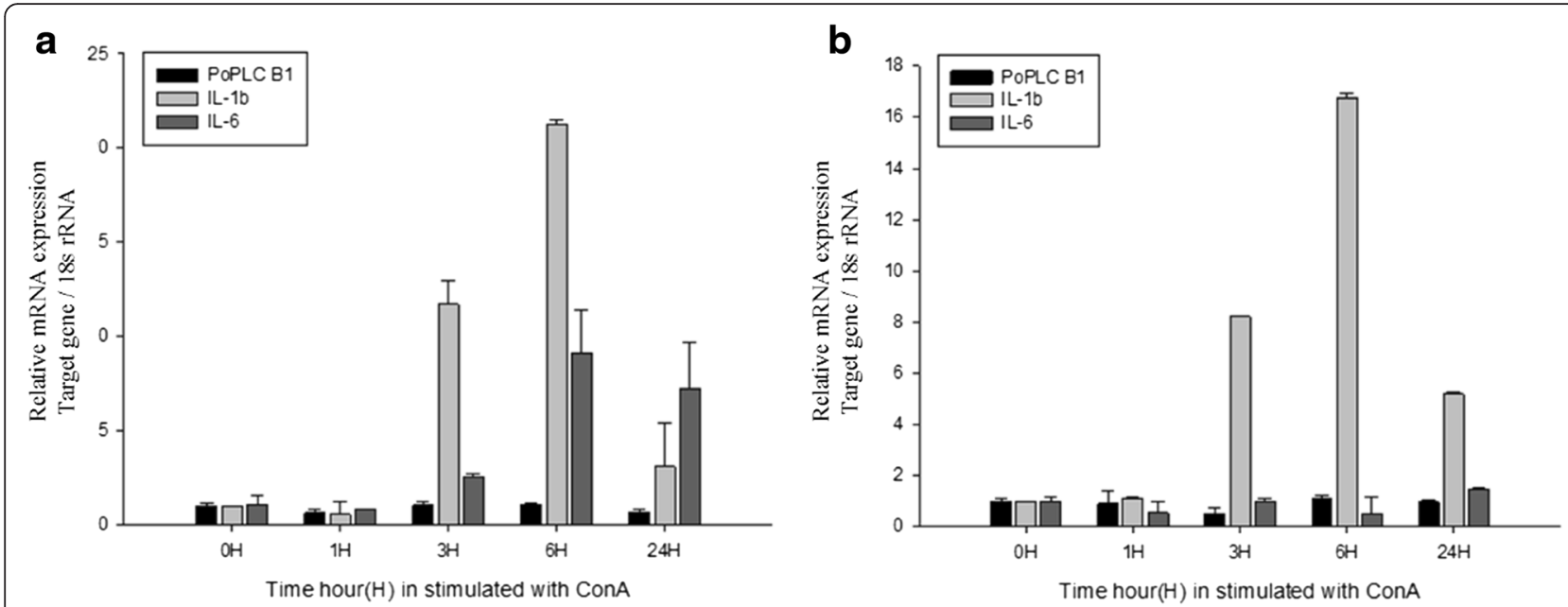

Fig. 3 Real-time PCR analysis of PoPLC- $\beta 1, I L-1 \beta, I L-6$, and 18SrRNA following stimulation with ConA from the a spleen and $\mathbf{b}$ kidney tissue at $0,1,3,6$, and $24 \mathrm{~h}$

\section{Environmental stress}

Changes of water temperature and salinity both affected the expression of PoPLC- $\beta 1$. To our surprise, salinity stress induced a greater effect than thermal stress. In the salinity stress condition, the expression level of PoPLC$\beta 1$ was increased by twofold in both the brain and heart and was slightly increased in the gills (Fig. 8a). Under temperature stress, PoPLC- $\beta 1$ expression increased by twofold in the heart compared to controls (Fig. 8b).

\section{Discussion}

In higher vertebrates, immunity can be broadly classified into adaptive immunity and innate immunity. Innate immunity is crucial for the recruitment of non-specific immune cells, including lymphocytes, dendritic cells, granulocytes, and macrophages, to the sites of infection by microorganisms and foreign substances. After these immune cells recognize the infection and kill the foreign cells, the adaptive immune system kicks in, which involves specific antigen presentation to $\mathrm{B}$ and $\mathrm{T}$ lymphocytes to fight the pathogen (Bonizzi and Karin 2004). Phospholipid second messengers produced by PLC- $\beta$ have been shown to play a significant role in $\mathrm{T}$ lymphocyte chemotaxis (Smit et al. 2003). Furthermore, the PLC- $\beta$ subfamily appears to be essential for the generation of $\mathrm{IP}_{3}$, DAG, and mobilization of $\mathrm{Ca}^{2+}$ (Bach et al. 2007). Moreover, PLC- $\beta$ plays a critical role in activation of chemoattractant-induced integrin, cellsubstrate adhesion, and in the movement and antibody production of B lymphocytes (Kawakami and Xiao 2013). Thus, PLC- $\beta$ s are involved in the specialization and activation of
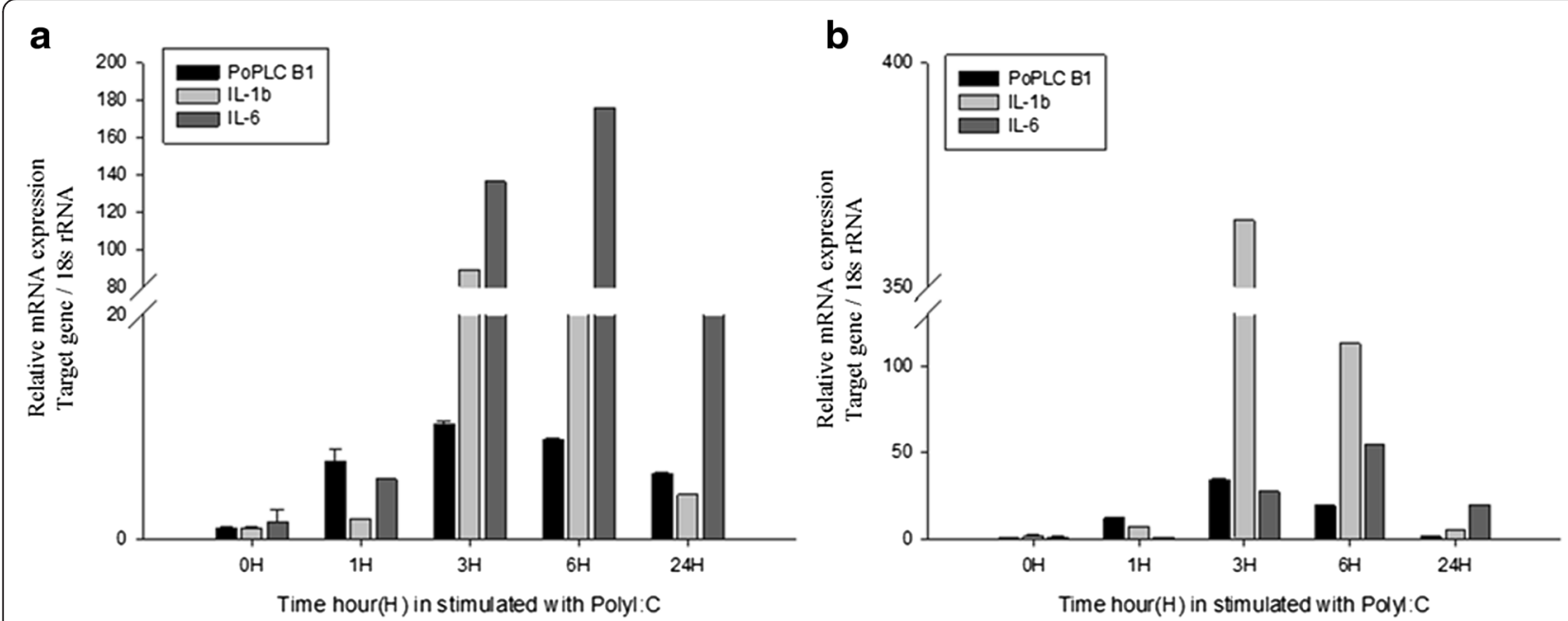

Fig. 4 Real-time PCR analysis of PoPLC- $\beta 1, I L-1 \beta, I L-6$, and 18SrRNA following stimulation with Polyl:C from the a spleen and $\mathbf{b}$ kidney tissue at 0 , $1,3,6$, and $24 \mathrm{~h}$ 

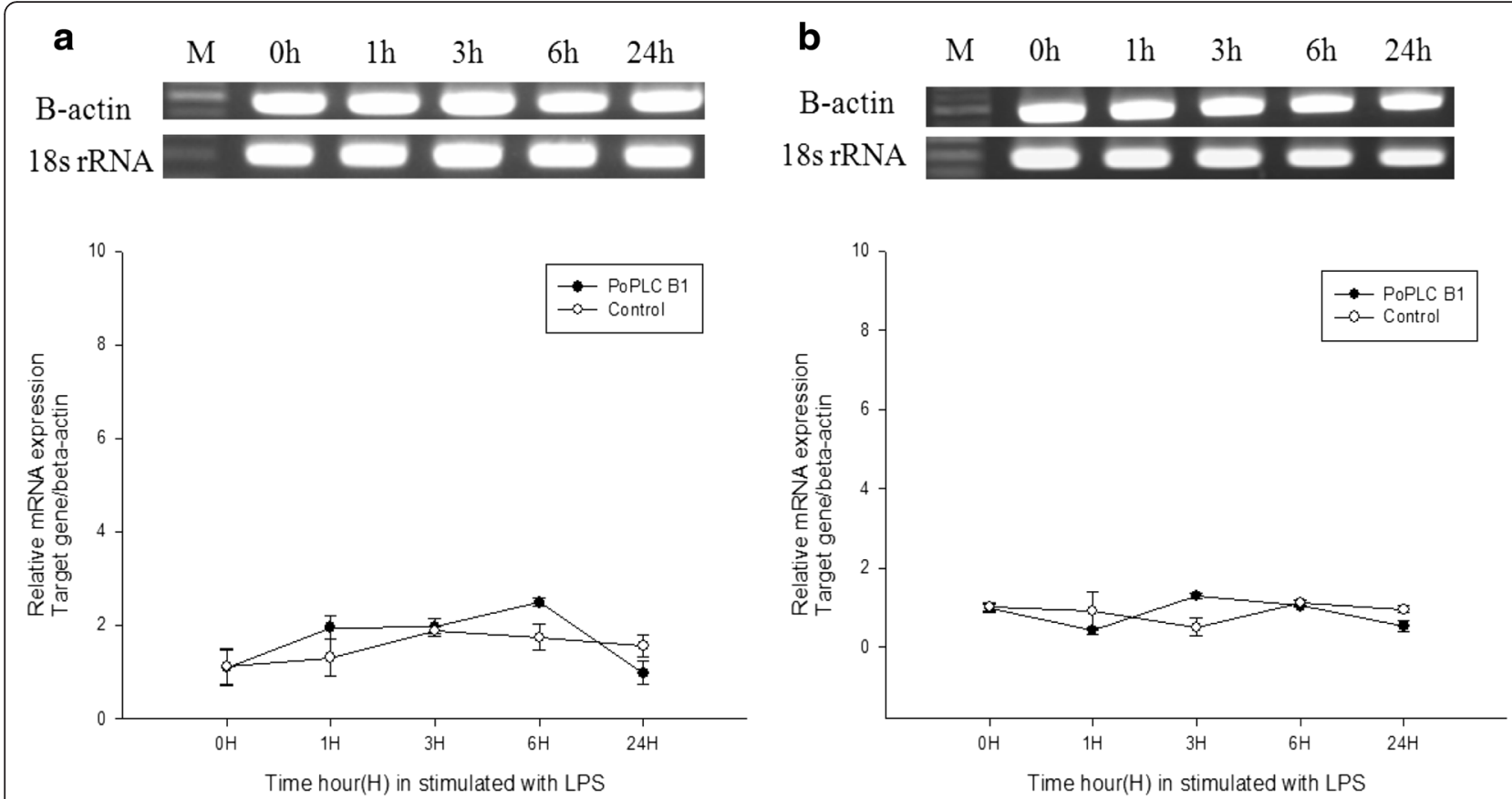

Fig. 5 RT-PCR and real-time PCR analysis of PoPLC- $\beta 1$ following stimulation with LPS and PBS (control) treatment from the a spleen and $\mathbf{b}$ kidney tissue at $0,1,3,6$, and $24 \mathrm{~h}$

immune cells, which regulate both the innate and adaptive immune responses (Forster et al. 1998). Previous studies have demonstrated that PLC- $\beta$ s show tissue-specific expression patterns and are regulated by $\mathrm{G}$ protein. Indeed, in mammals, PLC- $\beta 1$ is expressed in a wide range of tissues and cell types (Kawakami and Xiao 2013), including cardiac tissues (Jalili et al. 1999) and the brain (Suh et al. 2008).

PAMPs are characteristic molecular patterns that are highly conserved in different microorganisms (Savan and Sakai 2002). PAMPs, including LPS, ConA, and PolyI:C,
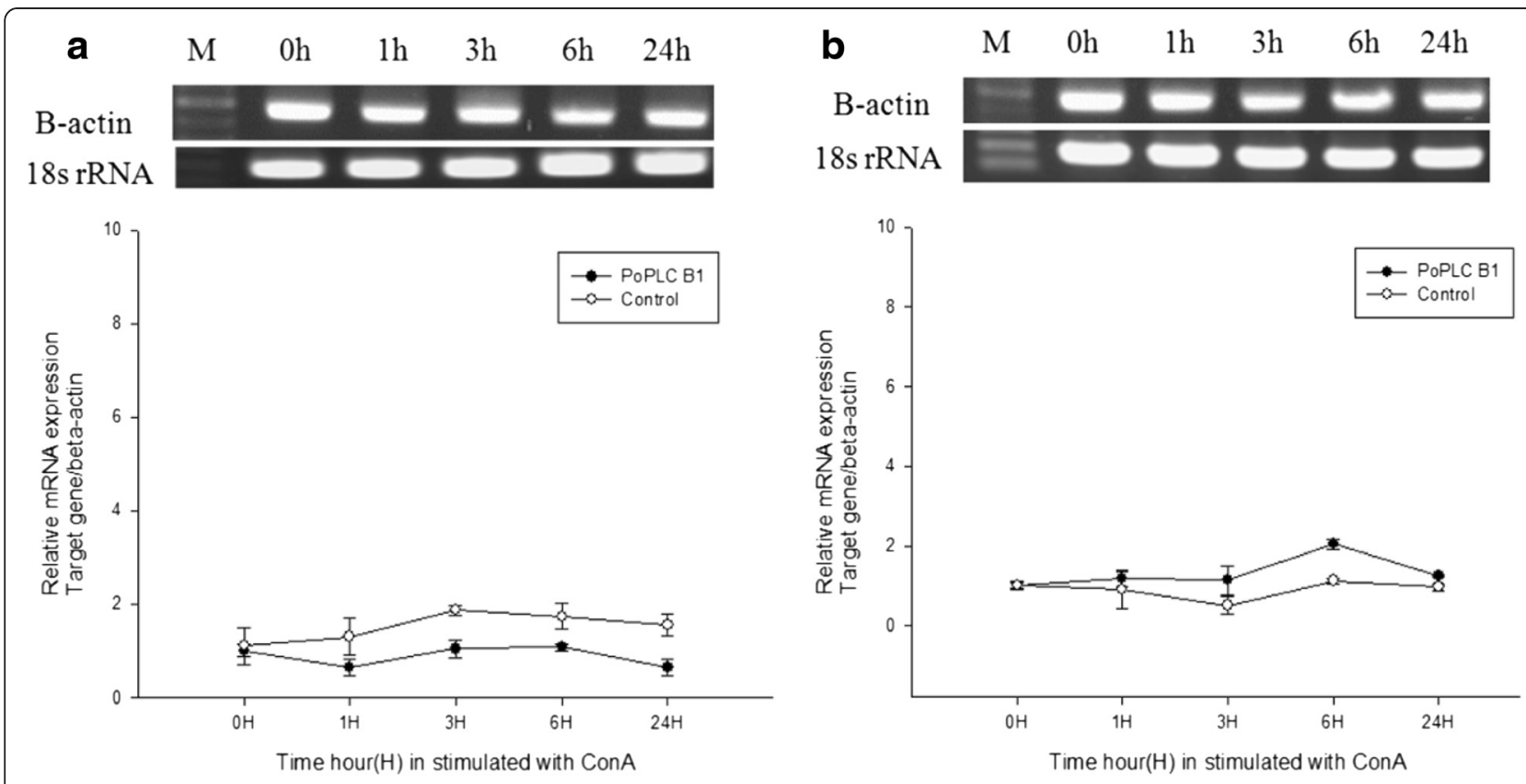

Fig. 6 RT-PCR and real-time PCR analysis of PoPLC- $\beta 1$ following stimulation with ConA and PBS (control) treatment from the a spleen and b kidney tissue at $0,1,3,6$, and $24 \mathrm{~h}$ 


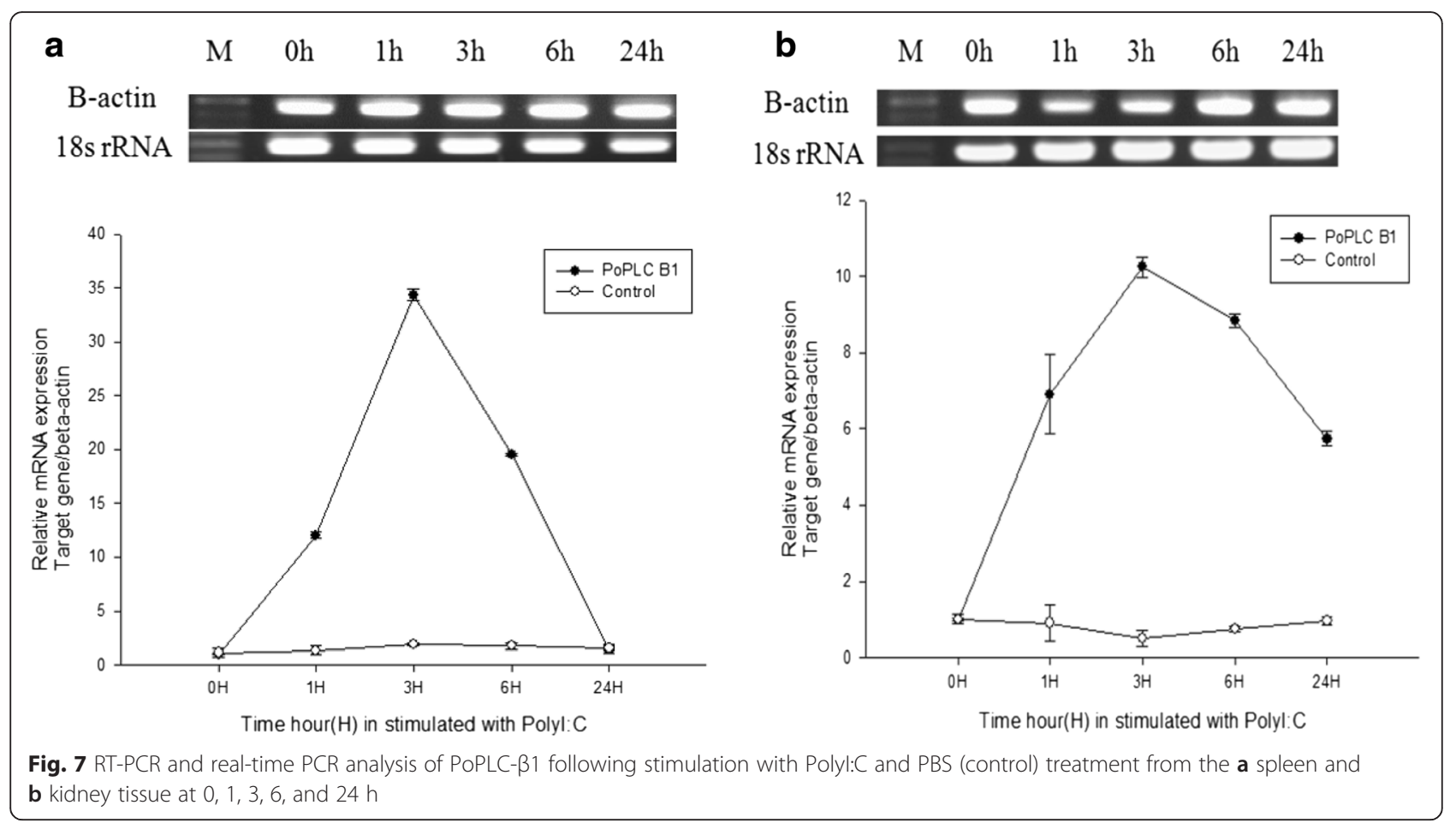

activate immune system responses in the host. In particular, LPS is a constituent of the outer membrane of gramnegative bacteria and induces the proliferation of $\mathrm{B}$ lymphocytes (Estepa and Coll 1992). ConA is a plant lectin isolated from jack bean (Canavalia ensiformis) that was originally identified as a mitogen for $\mathrm{T}$ lymphocytes. It has been shown to activate lymphocyte proliferation by the production of lymphokines and monokines and to activate tumor necrosis factor-alpha, macrophages, and neutrophils (Xue and Bigio 2005). ConA also triggers a mechanism similar to that induced by the specific worm allergen
(Panitch and McFarlin 1977). PolyI:C is a synthetic doublestranded RNA polymer that enhances the cytotoxicity of natural killer (NK) cells and macrophages (Biron 1997), increases interferon gamma (IFN- $\gamma$ ) production, and promotes lymphocyte adhesion to the endothelium (Doukas et al. 1994). Therefore, stimulation with LPS, ConA, and PolyI:C represent a challenge by bacteria, parasites, and viruses and were thus used to analyze the effects of immune challenge on PoPLC- $\beta 1$.

There is significant evidence for cell-mediated responses after PolyI:C stimulation. NK cells respond to PolyI:C by
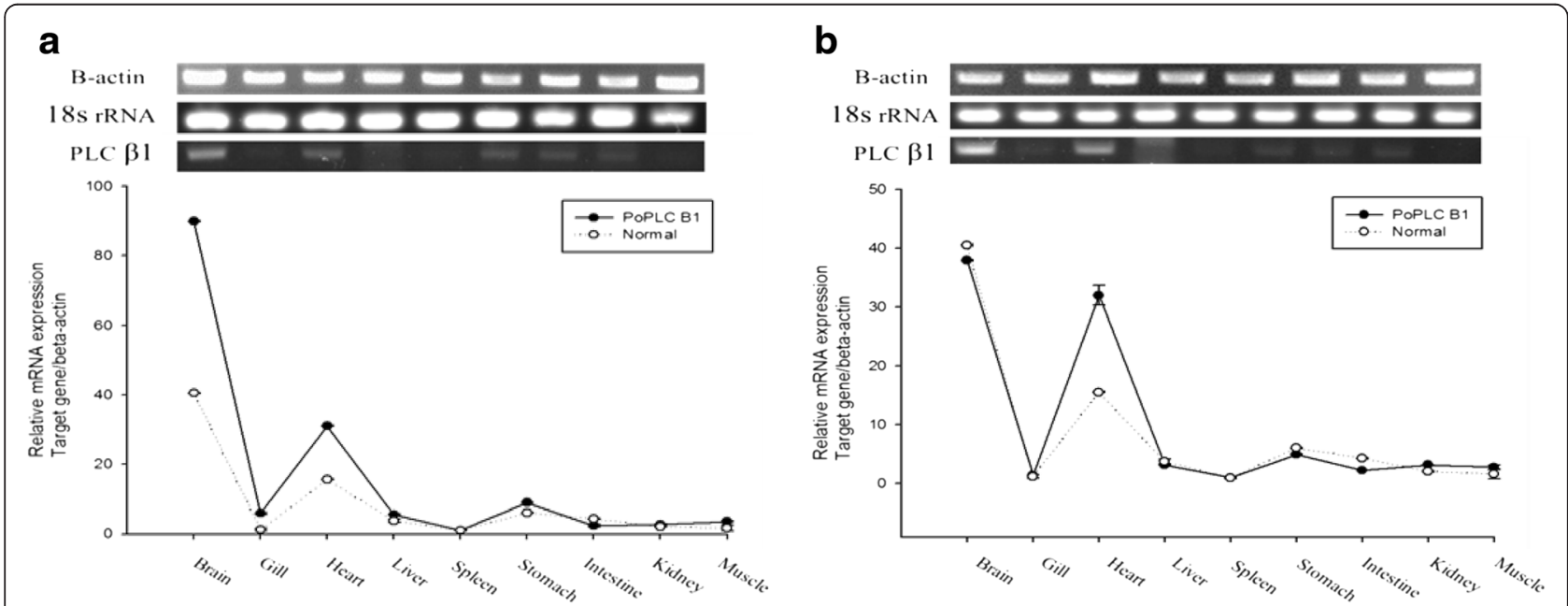

Fig. 8 RT-PCR and real-time PCR analysis of PoPLC- $\beta 1$ following environment stimulation. $\mathbf{a}$ Salinity stress and $\mathbf{b}$ temperature stress from various flounder tissues 
releasing proinflammatory cytokines such as IL-6 and IL8 , as well as the antiviral cytokine IFN- $\alpha$ (Schmidt et al. 2004; Longhi et al. 2009). In addition, PolyI:C induces inflammation and long-lasting $\mathrm{T}$ cell immunity (Salem et al. 2006; Trumpfheller et al. 2008; Stahl-Hennig et al. 2009). In the present study, we observed a rapid reaction in the spleen and kidney, within $3 \mathrm{~h}$ following Polyl:C infection. The mRNA levels of IL- $1 \beta$ and IL- 6 from the LPS, ConA, and PolyI:C infected organs were substantially upregulated and reached a peak at 3 or $6 \mathrm{~h}$ post injection. Our results indicated that PLC- $\beta 1$ activation by pathogens induces inflammation cytokines including IL-1 $\beta$ and IL- 6 production in the spleen and kidney tissues. Proinflammatory cytokines such as IL- $1 \beta$ and IL- 6 can modulate the PLC- $\beta$ and PIP 2 signaling pathway (Zini et al. 2003). PLC- $\beta$ activation pathway may possess the ability to modulate proinflammatory responses leading to downstream of NF-kB and interaction with G protein subunits (Townsend and Emala 2013). Also, PLC- $\beta$ has been known as a central mediator of chemotaxis and plays a critical role in the recruitment of leukocyte to inflammatory tissues (Lehmann et al. 2008). Therefore, these results shed insight into the role of PLC- $\beta 1$ in immune responses against pathogenic organism and provide a molecular foundation for further research, and monitoring in various teleost infection and immunity systems.

Stress factors in fish can be divided into two main categories: physical factors and chemical factors (Beckmann et al. 1990). The physical factors include salinity, temperature, density, and dissolved oxygen. In particular, salinity and temperature changes affect growth, reproduction, metabolism, osmoregulation, and immune function (Ackerman et al. 2000). Stress induced by changes in salinity has been associated with increased formation of ROS, which may considerably influence immune function and lead to oxidative stress (Paital and Chainy 2010; Shin et al. 2010). Furthermore, rapid changes in water temperature have been shown to enhance oxidative stress by increasing the amount of ROS generation in fish (Halliwell and Gutteridge 1999; Liu et al. 2007). Moreover, cells increase their antioxidant defense levels and associated enzymes in response to drastic temperature and salinity changes (Martinez-Alvarez et al. 2005). We observed increases in PoPLC- $\beta 1$ in response to temperature and salinity stress in the brain and heart. There is evidence that the PLC- $\beta 1$ level distinctly increases in response to ROS accumulation, which may play a role in protection against the damage induced by the physiological changes accompanying the stress response. This pattern of PLC- $\beta 1$ expression may explain the process of protection from damage in these physiological responses (Yasuda et al. 2008). Since PLC- $\beta 1$ can directly activate the $\mathrm{PKC} \alpha$ and $\mathrm{PKC} \beta \mathrm{II}$ isozymes, it is possible that overexpression of PLC- $\beta 1$ could protect cells from oxidant-induced cell death via the activation of PKC (Lee et al. 2000).

\section{Conclusions}

In conclusion, our results showed that the PLC- $\beta 1$ expression level increases in response to external stimuli mimicking immune challenge and stress in P. olivaceus. Research on the function of PLC- $\beta 1$ and mechanisms controlling its expression in teleosts is limited, and our results provide clear evidence that the olive flounder PLC- $\beta 1$ signal pathways may play a critical role in immune function at the cellular level and in inflammation reactions. In addition, PLC- $\beta 1$ appears to act as an oxidative-stress suppressor to prevent cell damage in fish. Therefore, these results should serve as a foundation for further research on the piscine immune system and related signal pathways of lower vertebrates.

\section{Abbreviations}

ConA, concanavalin A; DAG, diacylglycerol; ER, endoplasmic reticulum; IP3, inositol 1,4,5-trisphosphate; LPS, lipopolysaccharide; PAMPs, pathogen-associated molecular pathogens; PH, pleckstrin homology; PIP2, phosphatidylinositol-4,5bisphosphate PKC, protein kinase C; PLC, phosphoinositide-specific phospholipase C; Polyl:C, polyinosinic:polycytidylic acid; TIM, triose phosphate isomerase

\section{Acknowledgements}

This work was supported by a Research Grant of Pukyong National University (No 2014 0332).

\section{Authors' contributions}

SJ carried out the molecular genetic studies and manuscript writing. HY participated in the design of the study and data analysis. $\mathrm{HH}$ participated in the collection and assembly of the data. JK participated in its design and coordination and helped to draft the manuscript. All authors read and approved the final manuscript.

\section{Competing interests}

The authors declare that they have no competing interests.

\section{Disclosure}

The dataset(s) supporting the conclusions of this article is not included in the article.

\section{Author details}

${ }^{1}$ Department of Aquatic Life Medicine, Pukyong National University, Busan 608-737, South Korea. ${ }^{2}$ Department of Biotechnology, Pukyong National University, Busan 608-737, South Korea.

Received: 21 May 2016 Accepted: 21 May 2016

Published online: 10 June 2016

\section{References}

Ackerman PA, Forsyth RB, Mazur CF, Iwama GK. Stress hormones and the cellular stress response in salmonids. Fish Physiol Biochem. 2000;23:327-36.

Akiyama Y, Stevenson GW, Schlick E, Matsushima K, Miller PJ, Stevenson HC. Differential ability of human blood monocyte subsets to release various cytokines. J Leukoc Biol. 1985;37:519-30.

An KW, Kim NN, Shin HS, Kil G-S, Choi CY. Profiles of antioxidant gene expression and physiological changes by thermal and hypoosmotic stresses in black porgy(Acanthopagrus schlegeli). Comp Biochem Physiol A Mol Integr Physiol. 2010:156:262-8.

Bach TL, Chen QM, Kerr WT, Wang Y, Lian L, Choi JK, et al. Phospholipase C $\beta$ is critical for T cell chemotaxis. J Immunol. 2007;179:2223-7.

Beckmann RP, Mizzen LE, Welch WJ. Interaction of HSP70 with newly synthesized proteins: implications for protein folding and assembly. Science. 1990;248:850-4.

Benveniste EN. Cytokine actions in the central nervous system. Cytokine Growth Factor Rev. 1998:9:259-75.

Biron CA. Activation and function of natural killer cell responses during viral infections. Curr Opin Immunol. 1997;9:24-34. 
Bly JE, Clem LW. Temperature and teleost immune functions. Fish Shellfish Immunol. 1992;2:159-71.

Bonizzi G, Karin M. The two NF-kB activation pathways and their role in innate and adaptive immunity. Trends Immunol. 2004;25:280-8.

Borski RJ, Yoshikawa JSM, Madsen SS, Nishioka RS, Zabetian C, Bern HA, et al. Effects of environmental salinity on pituitary growth hormone content and cell activity in the euryhaline tilapia Oreochromis mossambicus. Gen Comp Endocrinol. 1994:95:483-94.

Bowden TJ. Modulation of the immune system of fish by their environment. Fish Shellfish Immunol. 2008;25:373-83.

Britoa R, Chimal ME, Rosas C. Effect of salinity in survival, growth, and osmotic capacity of early juveniles of Farfantepenaeus brasiliensis (Decapoda: Penaeidae). J Exp Mar Biol Ecol. 2000;244:253-63.

Bunney TD, Katan M. PLC regulation: emerging pictures for molecular mechanisms. Trends Biochem Sci. 2011;36:88-96.

Charo IF, Myers SJ, Herman A, Franci C, Connolly AJ, Coughlin SR. Molecular cloning and functional expression of two monocyte chemoattractant protein 1 receptors reveals alternative splicing of the carboxyl-terminal tails. Proc Natl Acad Sci. 1994;91:2752-6.

Chen CC, Wang JK, Lin SB. Antisense oligonucleotides targeting protein kinase Calpha, -beta I, or -delta but not -eta inhibit lipopolysaccharide-induced nitric oxide synthase expression in RAW 264.7 macrophages: involvement of a nuclear factor kappa B-dependent mechanism. J Immunol. 1998;161:6206-14.

Doukas J, Cutler AH, Mordes JP. Polyinosinic: polycytidylic acid is a potent activator of endothelial cells. Am J Pathol. 1994;145:137-47.

Estepa A, Coll JM. In vitro immunostimulants for optimal responses of kidney cells from healthy trout and from trout surviving viral haemorrhagic septicaemia virus disease. Fish Shellfish Immunol. 1992;2:53-68.

Forster R, Kremmer E, Schubel A, Breitfeld D, Kleinschmidt A, Nerl C, et al. Intracellular and surface expression of the HIV-1 coreceptor CXCR4/fusin on various leukocyte subsets: rapid internalization and recycling upon activation. J Immunol. 1998;160:1522-31.

Franci C, Wong LM, Van Damme J, Proost P, Charo IF. Monocyte chemoattractant protein-3, but not monocyte chemoattractant protein-2, is a functional ligand of the human monocyte chemoattractant protein-1 receptor. J Immunol. 1995:154:6511-7.

Guan ZB, Shui Y, Zhang SQ. Two related ligands of the TNF family, BAFF and APRIL, in rabbit: molecular cloning, 3D modeling, and tissue distribution. Cytokine. 2007;39:192-200.

Halliwell B, Gutteridge JMC. Free radicals in biology and medicine, vol. 3. Oxford: Oxford University Press; 1999. p. 86-187.

Jalili T, Takeishi Y, Walsh RA. Signal transduction during cardiac hypertrophy: the role of Gaq, PLC BI, and PKC. Cardiovasc Res. 1999;44:5-9.

Kawakami T, Xiao W. Phospholipase C-b in immune cells. Adv Biolog Regul. 2013; 53:249-57.

Keller R. Concanavalin A, a model 'antigen' for the in vitro detection of cellbound reaginic antibody in the rat. Clin Exp Immunol. 1973;13:139-47.

Kim JH, Kang JC. Oxidative stress, neurotoxicity, and non-specific immune responses in juvenile red sea bream, Pagrus major, exposed to different waterborne selenium concentrations. Chemosphere. 2015;135:46-52.

Kim JK, Lim S, Kim J, Kim S, Kim JH, Ryu SH, et al. Subtype-specific roles of phospholipase $C-\beta$ via differential interactions with PDZ domain proteins. Adv Enzym Regul. 2011;51:138-51.

Lee YH, Kim SY, Kim JR, Yoh KT, Baek SH, Kim MJ, et al. Overexpression of phospholipase $\mathrm{C}$ beta1 protects $\mathrm{NIH} 3 \mathrm{~T} 3$ cells from oxidative stress induced cell death. Life Sci. 2000;67:827-37.

Lehmann DM, Seneviratne AMPB, Smrcka AV. Small molecule disruption of G protein $\beta \gamma$ subunit signaling inhibits neutrophil chemotaxis and inflammation. Mol Pharmacol. 2008;73:410-8.

Liu Y, Wang WN, Wang AL, Wang JM, Sun RY. Effects of dietary vitamin E supplementation on antioxidant enzyme activities in Litopenaeus vannamei (Boone, 1931) exposed to acute salinity changes. Aquaculture. 2007;265:351-8.

Longhi MP, Trumpfheller C, Idoyaga J, Caskey M, Matos I, Kluger C, et al. Dendritic cells require a systemic type I interferon response to mature and induce CD4+ Th1 immunity with Poly IC as adjuvant. J Exp Med. 2009;206: 1589-602.

Manetti R, Annunziato F, Tomasevic L, Gianno V, Parronchi P, Romagnani S, et al. Polyinosinic acid:polycytidylic acid promotes $T$ helper type 1-specific immune responses by stimulating macrophage production of interferon-a and interleukin-12. Eur J Immunol. 1995;25:2656-60.
Martinez-Alvarez R, Morales AE, Sanz A. Antioxidant defenses in fish: biotic and abiotic factors. Rev Fish Biol Fish. 2005;15:75-88.

Otaegui D, Querejeta R, Arrieta A, Lazkano A, Bidaurrazaga A, Arriandiaga JR, et al. Phospholipase $\mathrm{Cb} 4$ isozyme is expressed in human, rat, and murine heart left ventricles and in HL-1 cardiomyocytes. Mol Cell Biochem. 2010;337:167-73.

Paital B, Chainy GBN. Antioxidant defenses and oxidative stress parameters in tissues of mud crab (Scylla serrata) with reference to changing salinity. Comp Biochem Physiol Part C: Toxicol Pharmacol. 2010;151:142-151.

Panitch HS, McFarlin DE. Experimental allergic encephalomyelitis: enhancement of cell-mediated transfer by concanavalin A. J Immunol. 1977;119:1134-7.

Rebecchi MJ, Pentyala SN. Structure, function, and control of phosphoinositidespecific phospholipase C. Physiol Rev. 2000;80:1291-335.

Rhee SG. Regulation of phosphoinositide-specific phospholipase C. Ann Rev Biochem. 2001;70:281-312.

Salem ML, El-Naggar SA, Kadima A, Gillanders WE, Cole DJ. The adjuvant effects of the toll-like receptor 3 ligand polyinosinic-cytidylic acid poly (I:C) on antigen-specific CD8+ T cell response are partially dependent on NK cells with the induction of a beneficial cytokine milieu. Vaccine. 2006;24:5119-32.

Sampaio LA, Bianchini A. Salinity effects on osmoregulation and growth of the euryhaline flounder Paralichthys orbignyanus. J Exp Mar Biol Ecol. 2002;269: 187-96.

Sasaki T, Irie-Sasaki J, Jones TG, Oliveira-dos-Santos AJ, Stanford WL, Bolon B, et al. Function of PI3Ky in thymocyte development, T cell activation, and neutrophil migration. Science. 2000;287:1040-6.

Savan R, Sakai M. Analysis of expressed sequence tags (EST) obtained from common carp, Cyprinus carpio L., head kidney cells after stimulation by two mitogens, lipopolysaccharide and concanavalin-A. Comp Biochem Physiol Part B: Biochem Mol Biol. 2002;131:71-82.

Schmidt KN, Leung B, Kwong M, Zarember KA, Satyal S, Navas TA, et al. APCindependent activation of NK cells by the Toll-like receptor 3 agonist doublestranded RNA. J Immunol. 2004;172:138-43.

Schreck CB, Solazzi MF, Johnson SL, Nickelson TE. Transportation stress affects performance of Coho Salmon, Oncorhynchus kisutch. Aquaculture. 1989;82:15-20.

Schütze S, Potthoff K, Machleidt T, Berkovic D, Wiegmann K, Krönke M. TNF activates NF-kB by phosphatidylcholine-specific phospholipase C-induced "acidic" sphingomyelin breakdown. Cell. 1992;71:765-76.

Seo JS, Jeon EJ, Park EM, Kim WJ, Kim NY, Lee EH, et al. Molecular cloning and characterization of PLCB1 (phospholipase $C$, beta 1) gene from the olive flounder, Paralichthys olivaceus. Genes Genomics. 2011;33:701-9.

Shin HS, Yoo JH, Min TS, Lee K-Y, Choi CY. The effects of quercetin on physiological characteristics and oxidative stress resistance in olive flounder, Paralichthys olivaceus. Asian-Australasian J Animal Sci. 2010;23:588-97.

Singer AU, Waldo GL, Harden TK, Sondek J. A unique fold of phospholipase Cbeta mediates dimerization and interaction with $\mathrm{G}$ alpha q. Nat Struct Mol Biol. 2002;9:32-6.

Smit MJ, Verdijk P, van der Raaij-Helmer EM, Navis M, Hensbergen PJ, Leurs R. CXCR3-mediated chemotaxis of human T cells is regulated by a Gi- and phospholipase C-dependent pathway and not via activation of MEK/p44/p42 MAPK nor Akt/PI-3 kinase. Blood. 2003:102:1959-65.

Song C, Hu CD, Masago M, Kariyai K, Yamawaki-Kataoka Y, Shibatohge M, et al. Regulation of a novel human phospholipase $\mathrm{C}, \mathrm{PLC} \varepsilon$, through membrane targeting by Ras. J Biol Chem. 2001;276:2752-7.

Stahl-Hennig C, Eisenblatter M, Jasny E, Rzehak T, Tenner-Racz K, Trumpfheller C, et al. Synthetic double-stranded RNAs are adjuvants for the induction of $T$ helper 1 and humoral immune responses to human papillomavirus in Rhesus Macaques. PLoS Pathog. 2009;5:e1000373.

Suh PG, Park Jl, Manzoli L, Peak JC, Katan M, Fukami K, et al. Multiple roles of phosphoinositide-specific phospholipase C isozymes. BMB Rep. 2008;41:415-34.

Tall E, Dormán G, Garcia P, Runnels L, Shah S, Chen J, et al. Phosphoinositide binding specificity among phospholipase C isozymes as determined by photo-crosslinking to novel substrate and product analogs. Biochem. 1997;36:7239-48.

Townsend EA, Emala CW. Quercetin acutely relaxes airway smooth muscle and potentiates $\beta$-agonist-induced relaxation via dual phosphodiesterase inhibition of PLCB and PDE4. Am J Physiol-Lung Cell Mol Physiol. 2013;305:L396-403.

Trumpfheller C, Caskey M, Nchinda G, Longhi MP, Mizenina O, Huang Y, et al. The microbial mimic polylC induces durable and protective CD4+ T cell immunity together with a dendritic cell targeted vaccine. Proc Natl Acad Sci U S A. 2008; 105:2574-9.

Wang P, Toyoshima S, Osawa T. Concanavalin A-induced translocation of part of the GTP-binding activity from the membrane to the cytosol in murine thymocytes. J Biochem. 1998;104:169-72. 
Ward SG, Cantrell DA. Phosphoinositide 3-kinases in T lymphocyte activation. Curr Opin Immunol. 2001;13:332-8.

Xue M, Bigio MRD. Immune pre-activation exacerbates hemorrhagic brain injury in immature mouse brain. J Neuroimmunol. 2005;165:75-82.

Yasuda E, Nagasawa K, Nishida K, Fujimoto S. Decreased expression of phospholipase C-b1 protein in endoplasmic Reticulum stress-loaded neurons. Biol Pharm Bull. 2008;31:719-21.

Zini N, Lisignoli G, Solimando L, Bavelloni A, Grassi F, Guidotti L, et al. IL1- $\beta$ and TNF-a induce changes in the nuclear polyphosphoinositide signalling system in osteoblasts similar to that occurring in patients with rheumatoid arthritis: an immunochemical and immunocytochemical study. Histochem Cell Biol. 2003;120:243-50

Submit your next manuscript to BioMed Central and we will help you at every step:

- We accept pre-submission inquiries

- Our selector tool helps you to find the most relevant journal

- We provide round the clock customer support

- Convenient online submission

- Thorough peer review

- Inclusion in PubMed and all major indexing services

- Maximum visibility for your research

Submit your manuscript at www.biomedcentral.com/submit
Biomed Central 